\title{
EVALUATION OF MICROCLIMATIC DATA ON LOCALITIES WITH DIFFERENT RATIO OF VEGETATION IN URBAN ENVIRONMENT
}

\author{
SOŇA KERESZTESOVÁ, JÁN KLEIN, ZDENKA RÓZOVÁ
}

Department of Ecology and Environmental Sciences, Faculty of Natural Sciences, Constantine the Philosopher University in Nitra, Tr. A. Hlinku 1, 94974 Nitra, Slovak Republic; e-mail: skeresztesova@ukf.sk, jan.klein@ukf.sk, zrozova@ukf.sk

\begin{abstract}
Keresztesová S., Klein J., Rózová Z.: Evaluation of microclimatic data on localities with different ratio of vegetation in urban environment. Ekológia (Bratislava), Vol. 33, No. 4, p. 301-306, 2014.

Many authors (Akbari, Taha, 1992; Čaboun, 2008; Klein, 2013; Keresztesová, 2013) proved the influence of vegetation on microclimate as well as on the decrease of heat islands. We were interested in how different ratio of vegetation and open spaces influences microclimatic factors. From April to July 2012 microclimatic factors of two different localities with respect to various ratios of vegetation and open spaces were observed in Nitra, Slovakia. More specifically, we observed the air temperature, relative air humidity and surface temperatures of four selected points in both localities. We have found out that in the park, i.e. in the locality with a higher portion of vegetation than open space was the course of temperatures more balanced, thanks to the attribute of vegetation to keep a stable microclimate. We have not observed any major differences between the monitored points variously located in the vegetation in one locality, but on the other hand, we have observed remarkable differences between the two monitored localities. We may allege that the ratio of vegetation and open spaces makes significant contribution to microclimatic conditions of urban environment.
\end{abstract}

Key words: vegetation growth, climate, surface temperature, urban environment, air humidity, air temperature.

\section{Introduction}

At present, it is widely known from a large number of studies by various authors (Delworth, Manabe, 1988, 1989; Matejka, Huzulák, 1987; Matejka et al., 2003; Porté et al., 2004; Reháčková, Pauditšová, 2006; Rózová et al., 2013; Spangenberg et al., 2008; Středová et al., 2011; Taha et al., 1988; Akbari et al., 2001) that woody plants have a favourable influence on the quality of air in the cities and at the same time fulfil its health, aesthetic and recreational function. Vegetation in the urban environment serves mainly to the ecological, social and partially the economic function. It has an influence on improving the microclimate, produces oxygen and biologically active substances that has mainly fytoncide and regenerative importance, absorbs harmful contaminants from the air, reduces noise levels, dust and gas pollutants by ionizing the air, positively influences the physical conditions, that are 
useful in the relationship towards the human organism, offers space and optimal conditions for recreation and rehabilitation of people, compositionally and aesthetically shapes the cities, affects the physiological and physical condition of humans (Supuka, 1991).

Especially nowadays, when there are remarkable differences in the temperatures of open country and the urban environment and so called heat islands, that negative effects of the microclimatic conditions in the cities are rising, mainly the woody plants and their microclimatic function are very welcomed in the urban environment. Spangenberg et al. (2008) proves the cooling effect of the park vegetation comparing to open square in an average of $2{ }^{\circ} \mathrm{C}$ and comparing to street canyon in an average of $2.5^{\circ} \mathrm{C}$ during noon, while the maximum difference was $6^{\circ} \mathrm{C}$. In comparison, the relative air humidity was $10 \%$ higher in the park. A continuation of the research by simulating the inclusion of trees to the street canyon by using a competent method had a limited cooling effect on the air temperature $\left(1.1^{\circ} \mathrm{C}\right)$, but it led to remarkable cooling of the street surface temperature about $12{ }^{\circ} \mathrm{C}$.

Differences in the total radiation balance and heat exchange are caused by the height and the density of vegetation, mainly by the surface of the leaf area. While the upper layer of the bare soil absorbs the radiation (dry soil absorbs less, humid soil more), in the vegetation most of the radiation is absorbed by leafs. Notable exchange of radiation in vegetation cover is realized mainly by thermal radiation from warmer parts to cooler parts of plants and by reflexion of the plant surface. Intensity and the structure of radiation in the low vegetation cover are always changing - it is decreasing in the direction towards soil according to how it is captured by the plant leafs. In case the vegetation cover is dense enough, the intensity of radiation at the soil surface is very low; it is just a fraction of the amount that reaches the outer layer of the vegetation (Petrík et al., 1986).

\section{Material and methods}

The air temperature, relative air humidity and surface temperature were observed at two monitored localities in the Nitra town from April to July 2012. At both of the localities, 4 monitoring spots (further MS) located mostly at the grass surface were observed: MS 1 - located in the vegetation, MS 2 - located at the edge of the vegetation, MS 3 - located in open space, MS 4 - located in $2 \mathrm{~m}$ distance from a building. Monitored localities had a land area $50 \times 50 \mathrm{~m}$. Localities were selected according to different conditions with regard to quantity and distribution of vegetation at these localities. Locality n.1 - Atrium of Faculty of Natural Sciences, CPU Nitra was selected according to specific conditions that are created by this closed urban element surrounding the vegetation inside of the atrium, which takes $20-30 \%$ of the area. The second monitored locality - The Park was selected as a locality with a high portion of vegetation (90-100\%). In this locality, greenery is represented by elements of vegetation abundant in all stages with different textures and structures. Locality according to high portion of vegetation presented by adult trees is relatively closed up for air velocity although there are open spaces as well, but those are in a smaller ratio to areas covered by vegetation. On both localities, there are areas covered by grass, but in a different portion to build up areas and areas covered by vegetation. Both areas were regularly monitored without respect to meteorological conditions always during one, in advance selected day during April till July 2012. Localities were monitored three times a day - in the morning, at noon and afternoon at 8:00, 15:00 and 22:00 hour. Surface temperature was recorded by infrared thermometer Testo 845 . Data about relative air humidity and air temperature were recorded by data logger LOG 32 .

Data were statistically processed in the software Statistica 8 by using nonparametric tests. For comparison of the data about air temperature $(\mathrm{T})$, relative air humidity $(\mathrm{H})$ and surface temperature (Ts) recorded at the monitored areas and monitored spots, Mann-Whitney test was used. In case of comparison of surface temperatures (Ts) of each monitored spot, Kruskal-Wallis test was used. 


\section{Results and discussion}

Values of relative air humidity and temperature recorded in one locality during mornings were almost the same. The most remarkable differences were recorded between the compared localities. Evident differences were recorded during noon and afternoon measurings, where the higher value was recorded in Atrium. This could be caused by higher portion of built up area and its attribute to accumulate the direct sun radiation; let us say, its emitation to inner environment without more evident air circulation. Average difference between the air temperature and humidity between the monitored localities was $3.88^{\circ} \mathrm{C}$ and $10.4 \%$, while the average differences in air temperatures and humidity in ambit of one locality in the vegetation and out of vegetation were $0.66{ }^{\circ} \mathrm{C}$ and $1.62 \%$ in the atrium $0.73{ }^{\circ} \mathrm{C}$ and $4.12 \%$ in the park (see Table 1).

$\mathrm{T}$ a b l e 1 . Average differences in air temperature $\left(\Delta \mathrm{T}\left({ }^{\circ} \mathrm{C}\right)\right)$ and relative air humidity $(\Delta \mathrm{H}(\%))$ between the Atrium and the Park, and between areas covered by vegetation and areas without vegetation (VG/wVG) in the Atrium and the Park.

\begin{tabular}{|l|c|c|c|}
\cline { 2 - 4 } \multicolumn{1}{c|}{} & Atrium - park & Atrium VG/wVG & Park VG/w VG \\
\hline $\boldsymbol{\Delta} \mathbf{T}\left({ }^{\circ} \mathbf{C}\right)$ & 3.88 & 0.66 & 0.73 \\
\hline$\Delta \mathbf{H}(\%)$ & 10.4 & 1.62 & 4.12 \\
\hline
\end{tabular}

Average air temperatures recorded during mornings were higher in the park vegetation and even out of vegetation (Fig. 1). This effect could be caused by the structure of vegetation present at the park that serves as an insulant for its microclimate. On the contrary, the data recorded at noon were higher in the Atrium. These differences were statistically significant at the level of significance $\alpha=0.01$. This fact claims the influence of built up space of the Atrium at the urban climate and at creation of heat island. The assumption, that the air humidity in the Park is higher than in the Atrium was proved. The difference in air humidity and the Atrium was higher inside and outside the vegetation. It is caused by the structure of vegetation and its amount. The data recorded during noon were quite similar in both localities. Inside the vegetation formation the average air temperature was lower than outside the vegetation. Similar situation was at the Park. The results proved that vegetation has a remarkable cooling effect in any of its forms and amounts, what has also been previously proven by Klein (2013) (see Table 1). Comparison of surface temperatures of both localities points at a similar course of values recorded during morning in both localities, as well as at the monitored spots (Fig. 2 ). The average temperature of monitored spots was slightly higher in the park than in the Atrium, but the difference was not statistically significant. Higher differences were recorded during afternoon in the Atrium. The highest differences were recorded at noon; higher data were recorded at the Atrium and in the vegetation, at the edge of the vegetation and outside the vegetation, which is influenced by the built up area as well as the different structure of arid grass cover with the attribute to accumulate the direct sun radiation, i.e. its reflection. The highest temperature was recorded at the monitored spot 2 with the value $61.3^{\circ} \mathrm{C}$. These extremely high values were recorded by Čaboun (2008) at the arid soil and moss. Park with 
its structure and connection of vegetation mainly near the open spaces has a positive effect on grass cover. Interesting is the difference of temperatures between the localities at the monitored spot $2 \mathrm{~m}$ from a building (MS 4), where the average temperature was higher in the Park, thus counter to the other monitored spots. Differences of surface temperatures between the vegetation and the open space were higher in the Atrium. Similarly, Reháčková, Pauditšová (2006) assessed the difference between surface temperatures of vegetation and open spaces. Even solitary tree has a significant cooling effect on surface temperatures, especially during hot summer days (Reháčková, Pauditšová, 2006). In the Park, this difference was lower; let us say, it created more balanced surface temperatures (Rózová et al., 2013). Average difference of surface temperatures between the spots located in the vegetation (MS 1) was $4.52{ }^{\circ} \mathrm{C}$, at the edge of vegetation (MS 2) the difference was $3.91{ }^{\circ} \mathrm{C}$, at the open space covered by grass (MS 3) the difference was $6.03{ }^{\circ} \mathrm{C}$ and at the spot located in $2 \mathrm{~m}$ from a building (MS 4) was $1.67^{\circ} \mathrm{C}$ (see Table 2).

$\mathrm{T} \mathrm{a} \mathrm{b} \mathrm{l} \mathrm{e} \mathrm{2.} \mathrm{Average} \mathrm{surface} \mathrm{temperatures}\left(\mathrm{Ts}\left({ }^{\circ} \mathrm{C}\right)\right)$ at monitored spots of both localities and differences between temperatures $\left(\Delta \mathrm{T}\left({ }^{\circ} \mathrm{C}\right)\right)$ in the Atrium and the Park at the monitored spots.

\begin{tabular}{|l|c|c|c|}
\cline { 2 - 4 } \multicolumn{1}{c|}{} & \multicolumn{2}{c|}{ Ts $\left({ }^{\circ} \mathbf{C}\right)$} & \multicolumn{1}{c}{} \\
\cline { 2 - 4 } \multicolumn{1}{c|}{} & Atrium & Park & $\Delta \mathrm{T}\left({ }^{\circ} \mathbf{C}\right)$ \\
\hline $\mathbf{1}$ & 21.98 & 17.47 & $\mathbf{4 . 5 2}$ \\
\hline $\mathbf{2}$ & 22.31 & 18.40 & $\mathbf{3 . 9 1}$ \\
\hline $\mathbf{3}$ & 26.84 & 20.81 & $\mathbf{6 . 0 3}$ \\
\hline $\mathbf{4}$ & 17.83 & 19.49 & $\mathbf{1 . 6 7}$ \\
\hline
\end{tabular}

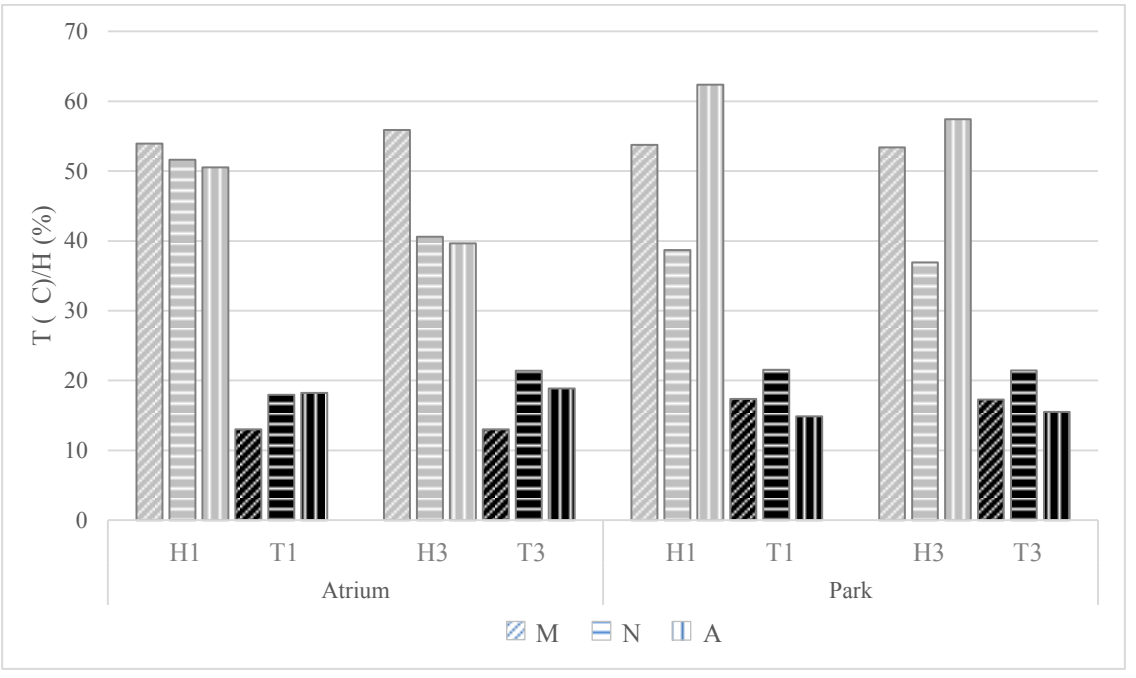

Fig. 1. Comparison of average temperature and relative air humidity in the Atrium and the Park, as well as inside and outside the vegetation in particular localities (T1 - air temperature in the vegetation, $\mathrm{H} 1$ - relative air humidity in the vegetation, T3 - temperature outside the vegetation, H3 - relative air humidity outside the vegetation, $\mathrm{M}$ values of morning data, $\mathrm{N}$ - values of noon data, $\mathrm{A}$ - values of afternoon data. 


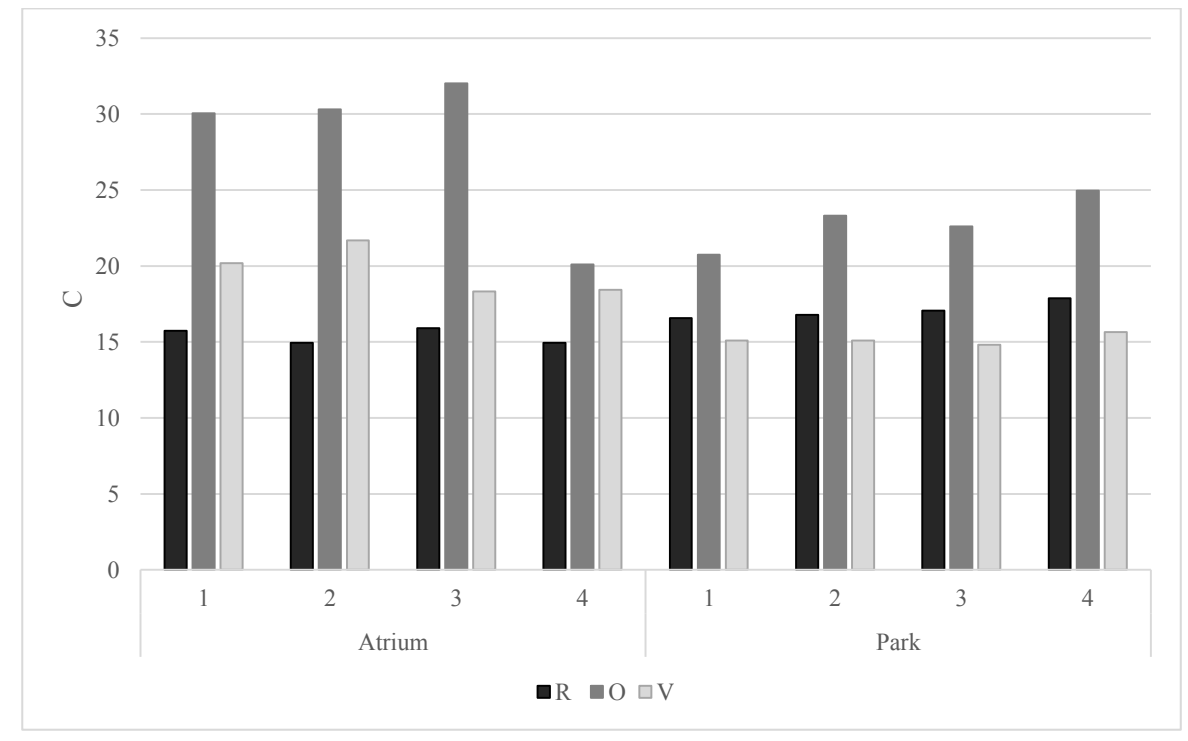

Fig. 2. Comparison of average surface temperatures between the Atrium and the Park, as well as mutually among particular surfaces of both localities (Surfaces: MS 1 - vegetation, MS 2 - edge of vegetation, MS 3 - outside the vegetation, MS 4-2 m from the building, M - values of morning data, O - values of noon data, A - data of afternoon data).

\section{Conclusion}

The research confirmed the influence of vegetation on microclimate of urban areas. Similarly as in previous researches, the influence of vegetation on surface temperature of monitored surfaces was approved. Localities with higher percentage of vegetation are in comparison to areas with higher portion of built up areas are in average of $1{ }^{\circ} \mathrm{C}$ cooler (Keresztesová et al., 2013). The surfaces have influence on air temperature and relative air humidity as well. Soil humidity affects the evapotranspiration and limits the influence of vegetation primarily on relative air humidity (Rózová et al., 2013). The structure of vegetation bears an important role, as it positively influences the microclimatic conditions according to thermal comfort of people; especially during summer months. Park, as a spacious area of vegetation creates a stable microclimate; meanwhile even smaller vegetation structure has important microclimatic effect. The microclimatic function of vegetation was confirmed and the importance of landscaping was highlighted - especially trees in urban environment are important not just as aesthetic element, but as a functional element too.

\section{Acknowledgements}

This study is a result of the project implementation: Environmentálne aspekty urbanizovaného prostredia, ITMS: 26220220110, supported by the Research \& Development Operational Programme funded by the ERDF. 


\section{References}

Akbari, H. \& Taha H. (1992). The impact of trees and white surfaces on residential heating and cooling energy use in four Canadian cities. Energy, 17(2), 141-149. DOI: 10.1016/0360-5442(92)90063-6.

Akbari, H., Pomerantz, M. \& Taha H. (2001). Cool surfaces and shade trees to reduce energy use and improve air quality in urban areas. Solar Energy, 70(3), 295-310. DOI: 10.1016/S0038-092X(00)00089-X.

Čaboun, V. (2008). Influence of vegetation on decreasing surface temperatures and air temperature during extreme summer heats (in Slovak). In J. Rožnovský \& T. Litschmann (Eds.), Bioklimatologické aspekty hodnocení procesů $v$ krajině. Mikulov 9. - 11.9.2008.

Delworth, T.L. \& Manabe S. (1988). The influence of potential evaporation on the variability of simulated soil wetness and climate. New Jersey: Princeton University.

Delworth, T.L. \& Manabe S. (1989). The influence of soil wetness on near-surface atmospheric variability. New Jersey: Princeton University.

Keresztesová, S., Strelková, M. \& Rózová Z. (2013). Influence of vegetation on surface temperature in urban areas. Folia Oecologica, 40(1), 50-54.

Klein, J. (2013). Evaluation of microclimatic parameters in selected vegetation growths of urban environment of Nitra city (in Slovak). Final Diploma Thesis, UKF, Nitra.

Matejka, F. \& Huzulák J. (1987). Analysis of vegetation microclimate (in Slovak). Bratislava: VEDA, vydavatel'stvo SAV.

Matejka, F., Rožnovský, J., Hurtalová, T. \& Janouš D. (2003). Current state and perspectives of microclimate of vegetation research (in Slovak). In J. Rožnovský \& T. Litschmann (Eds.), Seminář „Mikroklima porostü“ (pp. 1-14). Brno.

Petrík, M., Havlíček, P., Uhrecký, I. (1986). Forestry bioclimatology (in Slovak). Zvolen: TU Zvolen.

Porté, A., Huard, F. \& Dreyfus P. (2004). Microclimate beneath pine plantation, semi-mature pine plantation and mixed broadleaved-pine forest. Agric. For. Meteorol., 126(1-2), 175-182. DOI: 10.1016/j.agrformet.2004.06.001.

Reháčková, T., Pauditšová, E. (2006). Vegetation in the urban environment (in Slovak). Bratislava: Cicero.

Rózová, Z. et al. (2013). Environmental aspects of urban environment (in Slovak). Nitra: FPV UKF.

Spangenberg, J., Shinzato, P., Johansson, E. \& Duarte D. (2008). Simulation of the influence of vegetation on microclimate and thermal comfort in the city of São Paulo. Rev. SBAU, 3(2), 1-19.

Středová, H. et al. (2011). Microclimate and mezoclimate of towns, microclimate of vegetation (in Czech). Praha: ČHMÚ.

Supuka, J. (1991). Ecological principles of creation and protection of greenery (in Slovak). Bratislava: VEDA, vydavatel'stvo SAV.

Špánik, F. \& Šiška B. (2004). Biometeorology (in Slovak). Nitra: SPU Nitra.

Taha, H.G., Akbari, H. \& Rosenfeld A.H. (1988). Vegetation canopy micro-climate: a field project in Davis, California. Laboratory Report-24593. Berkley: Lawrence Berkley in Davis. 